\title{
Role of Adenosine Triphosphate and Adenosine in Oxygen-Induced Pulmonary Vasodilation in Fetal Lambs $^{1}$
}

\author{
G. GANESH KONDURI, CLARISSE T. GERVASIO, AND ANDREAS A. THEODOROU \\ Departments of Pediatrics, Children's Hospital of Michigan, Hutzel Hospital and Wayne State University School \\ of Medicine, Detroit, Michigan 48201
}

\begin{abstract}
We investigated the hypothesis that purine nucleotides, ATP and adenosine, mediate the pulmonary vasodilation that occurs at birth in response to an increase in arterial $\mathrm{O}_{2}$ pressure $\left(\mathrm{PaO}_{2}\right)$. We studied 20 fetal lambs 1 to $3 \mathrm{~d}$ after placement of intravascular catheters and a flow transducer around left pulmonary artery. In 16 lambs, we investigated the effects of 1 ) an increase in fetal $\mathrm{PaO}_{2}$ on ATP levels in pulmonary circulation and 2) 8-phenyltheophylline (8-PT) and cibacron blue, antagonists of receptors for adenosine and ATP, on pulmonary vasodilation caused by increased $\mathrm{PaO}_{2}$. In four other lambs, we investigated the specificity of 8-PT and cibacron blue for purine receptors by investigating their effects on pulmonary vasodilation caused by acetylcholine, bradykinin, and nitroprusside. The fetal $\mathrm{PaO}_{2}$ increased by $7 \pm 2$ during administration of $100 \% \mathrm{O}_{2}$ to the pregnant ewe, resulting in a 3-fold decrease in PVR and increase in pulmonary blood flow. Blood and plasma concentrations of ATP in fetal pulmonary artery and left atrium increased significantly during the increase in fetal $\mathrm{PaO}_{2}$. 8-PT and cibacron blue caused increases in baseline pulmonary and systemic vascular pressures and pulmonary vascular resistance and inhibited the pulmonary vasodilation caused by $\mathrm{O}_{2}$. 8-PT and cibacron blue did not alter the pulmonary vascular effects of acetylcholine, bradykinin, and nitroprusside. An increase in baseline pulmonary vascular resistance caused by infusion of $\mathrm{U} 46619$ (in four lambs) did not alter the pulmonary vasodilation caused by $\mathrm{O}_{2}$. In summary, $\mathrm{O}_{2-}$ induced pulmonary vasodilation is accompanied by increased ATP levels in pulmonary circulation and is attenuated by antagonists of purine receptors. Adenosine and ATP are important mediators of $\mathrm{O}_{2}$-induced pulmonary vasodilation in fetal lambs. (Pediatr Res 33: 533-539, 1993)
\end{abstract}

\section{Abbreviations}

PVR, pulmonary vascular resistance 8-PT, 8-phenyltheophylline

ANOVA, analysis of variance

$\mathrm{PaO}_{2}$, arterial $\mathrm{O}_{2}$ pressure

$\mathrm{PaCO}_{2}$, arterial $\mathrm{CO}_{2}$ pressure

EDNO, endothelium-derived nitric oxide

Received June 23, 1992; accepted January 12, 1993.

Correspondence and reprint requests: G. Ganesh Konduri, M.D., Department of Pediatrics, Hutzel Hospital, 4707 St. Antoine Blvd., Detroit, MI 48201.

Supported by grants from the American Heart Association of Michigan, American Lung Association of Michigan, and Children's Hospital of Michigan Endowment Fund.

${ }^{1}$ Presented in part at the Society for Pediatric Research meeting, Baltimore, MD, May 1992
$\mathrm{Hb} \mathrm{O}_{2}$ Sat, hemoglobin $\mathrm{O}_{2}$ saturation $\mathrm{RBC}$, red blood cell

PVR in the fetus undergoes a dramatic decrease at birth, accompanied by a 10 -fold increase in pulmonary blood flow (1). The factors that decrease PVR at birth include onset of ventilation (2) and exposure to higher $\mathrm{O}_{2}$ tension (3-6). Previous studies done in fetal lambs have shown that distension of lung alone causes a small decrease in PVR and that this response is modulated by prostaglandins $(7,8)$. Increase in $\mathrm{O}_{2}$ tension in the fetus to postnatal levels, however, causes the 10 -fold increase in pulmonary blood flow and decrease in PVR that occur at birth (6). The effect of $\mathrm{O}_{2}$ on PVR appears to be independent of prostaglandin synthesis $(8,9)$. Recent studies $(10)$ have shown that vascular endothelium regulates the decrease in PVR at birth in fetal lambs by synthesis of EDNO. However, the factors that stimulate the synthesis of EDNO at birth are not known.

We previously reported that adenosine and ATP are pulmonary vasodilators in fetal (11) and postnatal lambs $(12,13)$ and that they dilate the pulmonary vessels by stimulation of $P_{1}$ and $\mathrm{P}_{2}$ purinergic receptors. We also reported (11) that the blood ATP and adenosine levels in fetal pulmonary circulation are lower than in postnatal lambs. ATP and adenosine have been shown to stimulate EDNO release in pulmonary vessels of newborn (14) and fetal lambs (15). We therefore proposed the hypothesis that increased synthesis and release of ATP by the vascular endothelial cells and/or red cells into plasma, in response to an increase in $\mathrm{PaO}_{2}$ at birth, causes pulmonary vasodilation in fetal lambs. The ATP released by the cells is rapidly converted by ectoenzymes to adenosine (16), which causes pulmonary vasodilation by stimulation of a different $\left(\mathrm{P}_{1}\right)$ receptor from ATP. The pulmonary vascular effects of adenosine are blocked by 8-PT, a $\mathrm{P}_{1}$ receptor antagonist, and the effects of ATP are blocked by cibacron blue, a $\mathrm{P}_{2}$ receptor antagonist (11). However, it is not known whether these purine antagonists have nonspecific effects on other vasodilator mechanisms in pulmonary circulation. It is also not clear whether the effect of purine antagonists on baseline vascular tone have an independent influence on pulmonary vasodilator response to $\mathrm{O}_{2}$.

Previous studies $(17,18)$ evaluating the role of purine nucleotides in the mediation of systemic vascular responses to hypoxia have only used adenosine antagonists to study their role. A significant attenuation of response to hypoxia was not seen, possibly due to a lack of inhibition of ATP, which also causes vasodilation. We therefore investigated the role of purine nucleotides in the mediation of $\mathrm{O}_{2}$-induced pulmonary vasodilation by using a combination of antagonists for both receptors. The objectives of this study were to determine the effects of 1 ) increased $\mathrm{PaO}_{2}$ on blood and plasma concentrations of ATP in 
fetal pulmonary circulation; 2) purine receptor antagonists, 8$\mathrm{PT}$ and cibacron blue on $\mathrm{O}_{2}$-induced pulmonary vasodilation in fetal lambs; 3) specificity of 8-PT and cibacron blue for $\mathrm{P}_{1}$ and $\mathrm{P}_{2}$ receptors by investigating their effects on pulmonary vasodilation caused by acetylcholine, bradykinin, and nitroprusside; and 4) the effect of an increase in baseline PVR caused by $\mathrm{U} 46619$ on pulmonary vascular effects of $\mathrm{O}_{2}$.

\section{MATERIALS AND METHODS}

Twenty fetal lambs were studied at $128 \pm 4 \mathrm{~d}$ of gestation (term gestation, $145 \mathrm{~d}$ ). Four fetal lambs were studied to investigate the effects of 8-PT and cibacron blue on pulmonary vasodilation caused by acetylcholine, bradykinin, and nitroprusside. Each of these four lambs were studied three times on separate days. Sixteen fetal lambs were studied to investigate the effect of increased $\mathrm{PaO}_{2}$ on fetal PVR and blood ATP levels and the effects of 8-PT and cibacron blue on $\mathrm{O}_{2}$-induced pulmonary vasodilation. Each of the 16 lambs was studied twice on separate days. The order of the studies was randomized for each lamb, and lambs were allowed to recover for $24 \mathrm{~h}$ between studies. Four of these 16 fetal lambs were also studied on a separate day to evaluate the effects of an increase in baseline PVR, caused by infusion of a thromboxane mimetic $\mathrm{U} 46619$ (14), on $\mathrm{O}_{2}$-induced pulmonary vasodilation. The order of the three studies done on these four lambs was also randomized with a 24-h interval between studies. The study was approved by the Animal Investigations Committee of Wayne State University (Detroit, MI).

Surgical preparation. The ewe underwent a sterile surgical procedure under general anesthesia with isoflurane and $\mathrm{O}_{2}$ administered via an endotracheal tube. The fetus was exposed by a midline laparotomy incision and an incision in the uterus close to the fetal head. Catheters made from Tygon tubing (Baxter Diagnostics Inc., McGaw Park, IL) were inserted into the ascending aorta and right atrium via the carotid artery and jugular vein. A left lateral thoracotomy was then done on the fetus to insert catheters into the left pulmonary artery and left atrium and an ultrasonic flow transducer (size $6 \mathrm{~S}$, Transonic Systems Inc., Ithaca, NY) around the left pulmonary artery. A large-bore catheter was placed in the amniotic cavity to replace amniotic fluid with lactated Ringer's solution and to measure the amniotic cavity pressure, which served as zero reference for fetal intravascular pressures. The catheters and cable for flow transducer were exteriorized to the flank of the ewe. The fetus was returned to the uterine cavity, and uterine and abdominal incisions were closed. Antibiotics (procaine penicillin, 2 million $U$, and gentamicin, $250 \mathrm{mg}$ intramuscularly) were administered to the ewe on the day of surgery and on each postoperative day.

Study protocol. Each animal was allowed to recover for 1 to 3 $\mathrm{d}$ before experiments were done. For a study, the ewe was placed in a cage in the study area and was allowed free access to alfalfa pellets and water. The fetal intravascular catheters and amniotic fluid catheter were connected to strain-gauge manometers (P23 $\mathrm{XL}$, Spectramed Electronics Inc., Critical Care Division, Oxnard, $\mathrm{CA}$ ), and the flow transducer was connected to an ultrasonic transit-time blood flow meter (Transonic Systems Inc.). Zero flow output from the flowmeter was used as baseline, and mean flow output above baseline was used as the mean pulmonary blood flow. Aortic, pulmonary arterial, left and right atrial pressures, and pulmonary blood flow were recorded on a Grass model 7D polygraph (Grass Instruments, Quincy, MA). The fetal PVR was calculated as the difference between left pulmonary arterial and left atrial pressures divided by left pulmonary flow, measured as $\mathrm{mL} / \mathrm{min}$.

Drug preparation. Acetylcholine hydrochloride and bradykinin were obtained from Sigma Chemical Co. (St. Louis, MO) in a powder form, and the solution for i.v. administration was prepared each day by mixing it with sterile $0.9 \%$ saline to give a final concentration of $100 \mu \mathrm{g} / \mathrm{mL}$ and $10 \mu \mathrm{g} / \mathrm{mL}$, respectively. Sodium nitroprusside was mixed with $5 \%$ dextrose water to give a final concentration of $10 \mu \mathrm{g} / \mathrm{mL}$. 8-PT was obtained from Sigma in a powder form, and the total dose of $20 \mathrm{mg}(7 \mathrm{mg} / \mathrm{kg}$ for the average weight of fetus) was dissolved in $3 \mathrm{~mL}$ of ethyl alcohol. Cibacron blue (Sigma) was dissolved in normal saline to provide the total dose of $15 \mathrm{mg}(5 \mathrm{mg} / \mathrm{kg})$ in $3 \mathrm{~mL}$ of solution. We previously reported (11) that these doses of purine antagonists cause attenuation of pulmonary vasodilation caused by adenosine and ATP infusions at doses of 0.08 to $2.5 \mu \mathrm{mol} / \mathrm{kg} / \mathrm{min}$. One mg of U46619 (Sigma) was dissolved in $1 \mathrm{~mL}$ of ethyl alcohol, and $100 \mu \mathrm{g}$ were subsequently dissolved in $50 \mathrm{~mL}$ of sterile water for infusion.

Protocol 1: investigation of specificity of purine antagonists. Four fetal lambs were studied three times each on separate days. Control experiments were done with infusion of acetylcholine in doses of 25,50 , and $100 \mu \mathrm{g} / \mathrm{min}$ into the right atrial line with a Harvard infusion pump (Harvard Apparatus, Co., Inc., So. Natick, MA). Each infusion rate was maintained for $10 \mathrm{~min}$, and variables were measured at the end of a 10-min infusion. The animal was allowed to recover for $10 \mathrm{~min}$ between doses and for 1 to $2 \mathrm{~h}$ after the last dose. Hemodynamic variables recovered to baseline by the end of $1 \mathrm{~h}$. Bradykinin was then infused into the right atrial line in doses of 2,5 , and $10 \mu \mathrm{g} / \mathrm{min}$ at $10-\mathrm{min}$ intervals, followed by recovery for 1 to $2 \mathrm{~h}$. Finally, nitroprusside was infused into the left pulmonary artery at doses of 2,5 , and $10 \mu \mathrm{g} / \mathrm{min}$ at $10-\mathrm{min}$ intervals. Hemodynamic variables were recorded at the end of a 10-min infusion of each dose of bradykinin and nitroprusside. The experiments lasted $6 \mathrm{~h}$ each day, and the pregnant ewes tolerated the studies well without agitation. On a separate day, the animals were given $20 \mathrm{mg}$ of 8-PT into the left pulmonary artery, and variables were recorded after $20 \mathrm{~min}$. The infusion of three vasodilators was then repeated in sequence, as described for control experiments. On a different day, the fetal lamb was given cibacron blue into the left pulmonary artery in a dose of $15 \mathrm{mg}$, and the infusion of three vasodilators was repeated. The doses of vasodilators were chosen based on pilot studies showing a range of 2- to 5-fold increase in pulmonary blood flow at these doses. The doses of 8-PT and cibacron blue chosen have been shown previously to cause attenuation of pulmonary vascular effects of adenosine and ATP, respectively (11). We used the same doses of blockers in our experiments with $\mathrm{O}_{2}$, as described below. We allowed the animals to recover for $24 \mathrm{~h}$ between studies with the $\mathrm{P}_{1}$ and $\mathrm{P}_{2}$ receptor blockers and randomized the order in which the studies were performed. The duration of the blockade caused by these drugs has not been investigated in fetal lambs, but the baseline hemodynamic variables before each study were comparable.

Protocol 2: effects of $\mathrm{O}_{2}$ on fetal pulmonary circulation before and after purine receptor blockade. Sixteen fetal lambs were studied twice each on separate days. For control experiments, baseline hemodynamic variables were recorded when the ewe was breathing room air. Blood samples were obtained from fetal pulmonary artery and left atrium to measure the blood and plasma concentrations of ATP and from fetal aorta to measure the arterial blood gas tensions and blood $\mathrm{pH}$. Blood samples for ATP determinations were drawn only during control experiments. The fetal $\mathrm{PaO}_{2}$ was then increased by exposing the pregnant sheep to $100 \% \mathrm{O}_{2}$ given via a plastic bag placed over the ewe's head at 20 to $30 \mathrm{~L} / \mathrm{min}$. The ewes were conditioned by having them breathe through the plastic bag on at least two occasions before the actual experiment. They tolerated the experiment well and did not show agitation. Accurso et al. (5) have reported a $5-\mathrm{mm} \mathrm{Hg}(0.7 \mathrm{kPa})$ increase in fetal $\mathrm{PaO}_{2}$ and a 3-fold increase in pulmonary flow by administration of $100 \% \mathrm{O}_{2}$ to the pregnant sheep. The maximal changes were reported to occur at $40 \mathrm{~min}$ after beginning of exposure to $\mathrm{O}_{2}$ in their studies, done at an altitude of $1500 \mathrm{M}$. However, we found that maximal response to $\mathrm{O}_{2}$ occurs at $20 \mathrm{~min}$ with an average increase in $\mathrm{PaO}_{2}$ of $7 \mathrm{~mm} \mathrm{Hg}(0.9 \mathrm{kPa})$ in our studies done at sea level. Hemodynamic variables were recorded, and blood samples were obtained for ATP levels and arterial blood gas tensions and $\mathrm{pH}$ at 
10 and $20 \mathrm{~min}$ after the beginning of exposure to $\mathrm{O}_{2}$. The ewe was then returned to room air and to the cage. After a 24-h interval, the second experiment was done on the same animal. Baseline variables were recorded, and the fetal lamb was given $20 \mathrm{mg}$ of 8-PT into the left pulmonary artery, followed after 10 min by $15 \mathrm{mg}$ of cibacron blue. These drugs were given to block both $P_{1}$ and $P_{2}$ purinergic receptors, respectively. Variables were recorded $20 \mathrm{~min}$ after administration of cibacron blue. The exposure of the ewe to $100 \% \mathrm{O}_{2}$ was then repeated as described for control experiments. Hemodynamic variables and arterial blood gases were checked 10 and $20 \mathrm{~min}$ after the beginning of exposure to $\mathrm{O}_{2}$. The volume of each blood sample was $0.5 \mathrm{~mL}$ each for blood and plasma ATP levels from pulmonary artery and left atrium and $0.3 \mathrm{~mL}$ for blood gas determination. The total volume of blood taken was $7 \mathrm{~mL}$ for each control study and $1 \mathrm{~mL}$ for studies done after the administration of purine blockers. The total volume of $8 \mathrm{~mL}$ represents $3 \%$ of blood volume (assuming $85 \mathrm{~mL} / \mathrm{kg}$ and average fetal weight of $2.9 \mathrm{~kg}$ ) taken over $2 \mathrm{~d}$ and did not affect the baseline hemodynamic variables.

Protocol 3: effect of U46619 infusion on $\mathrm{O}_{2}$-induced pulmonary vasodilation. Four of the 16 fetal lambs were given an infusion of U46619 into the left pulmonary artery in a dose of $0.75 \mu \mathrm{g} /$ min. Baseline variables were recorded $10 \mathrm{~min}$ after the beginning of infusion. The dose of U46619 was found to increase the pulmonary artery pressure and PVR to the same extent as 8-PT and cibacron blue. Exposure of the pregnant ewe to $100 \% \mathrm{O}_{2}$ was repeated as described above. Experiments with U46619 were done on a separate day, and the order of control, purine blocker, and U46619 experiments was randomized for each animal.

Assay for ATP. Blood samples for ATP levels were collected rapidly into heparinized syringes and were placed immediately into tubes with trichloroacetic acid kept at 0 to $4^{\circ} \mathrm{C}$ and into EDTA tubes. The samples were immediately centrifuged, and supernatant was separated and kept frozen at $-20^{\circ} \mathrm{C}$. Samples treated with trichloroacetic acid underwent immediate lysis of red cells, and the ATP levels in these samples represented the combined amount in red cells and plasma. Samples treated with EDTA allowed us to measure the levels in plasma alone. Assay for ATP was done using the firefly luciferin-luciferase bioluminescence method (19). ATP is consumed and light is emitted when firefly luciferase catalyzes the oxidation of P-luciferin. The amount of light emitted during the reaction is proportional to availability of ATP. Samples were diluted 1000 -fold with a 10 $\mathrm{mM}$ phosphate buffer and were run in triplicate against a 10point standard curve. Internal standardization for each sample was also done in triplicate using a $1-\mu \mathrm{M}$ solution of ATP $(10 \mu \mathrm{L} /$ $100 \mu \mathrm{L}$ of sample). Luminescence was measured using a Berthold Luminometer (Lumat LB 9501, EG\&G Berthold Analytical Instruments Inc., Nashua, NH). Blood and plasma ATP levels were expressed as $\mu \mathrm{mol} / \mathrm{L}$. The intraassay coefficient of variation was 1.3 to $2.6 \%$, and the interassay coefficient of variation was $7 \%$. The smallest detectable concentration of ATP using this method was $1 \mathrm{pmol} / \mathrm{L}$.

Statistical analysis. Data are expressed as means $\pm 1 \mathrm{SD}$. Baseline data obtained on different days for each experiment were compared by single-factor ANOVA for repeated measures to determine if baseline variables were similar on each day. Data obtained with each vasodilator in the control experiments were compared with those obtained after $\mathrm{P}_{1}$ and $\mathrm{P}_{2}$ blockers by twoway ANOVA for repeated measures (20). The control data obtained during exposure to $\mathrm{O}_{2}$ were compared with data obtained with purine blockers by two-way ANOVA for repeated measures. Blood ATP levels obtained during exposure to $\mathrm{O}_{2}$ were compared with baseline by single-factor ANOVA. When significant differences $(p<0.05)$ were found, a Duncan's multiplerange test was done to determine which means were different.

\section{RESULTS}

The fetal lambs were of normal weight $(2.9 \pm 0.4 \mathrm{~kg})$ and had normal blood $\mathrm{pH}(7.39 \pm 0.03)$ and $\mathrm{PO}_{2}(18 \pm 3$ torr or $2.5 \pm$ $0.5 \mathrm{kPa}$ ) at the time of study. Baseline variables measured on different days were comparable and showed no significant differences. Acetylcholine and bradykinin (Fig. 1) caused significant decreases in PVR and increases in pulmonary blood flow at all doses tested in the control experiments. 8-PT and cibacron blue increased the PVR from control. They did not alter the pulmonary vascular effects of acetylcholine and bradykinin. Nitroprusside (Fig. 2) caused a significant decrease in PVR and increase in pulmonary flow at 5- and $10-\mu \mathrm{g} / \mathrm{min}$ infusion rates. $8-\mathrm{PT}$ and cibacron blue attenuated the increase in pulmonary flow at 5$\mu \mathrm{g} / \mathrm{min}$ infusion rate of nitroprusside. However, the purine blockers did not alter the decrease in PVR caused by nitroprusside.

Exposure of the pregnant ewe to $100 \% \mathrm{O}_{2}$ resulted in significant increases in $\mathrm{PaO}_{2}, \mathrm{PaCO}_{2}$, and $\mathrm{Hb} \mathrm{O}$ Sat (Table 1). The increases in fetal $\mathrm{PaO}_{2}$ and $\mathrm{Hb} \mathrm{O}_{2}$ Sat with $\mathrm{O}_{2}$ in lambs pretreated with purine antagonists were comparable to those in control experiments. The blood $\mathrm{pH}$ showed a small but statistically significant decrease after the administration of purine blockers (Table 1). The blood ATP levels in the pulmonary artery increased at $20 \mathrm{~min}$ and in the left atrium at 10 and $20 \mathrm{~min}$ after beginning exposure to $\mathrm{O}_{2}$ in control experiments (Table 2). The plasma ATP levels in the pulmonary artery and left atrium increased at 10 and 20 min after the increase in fetal $\mathrm{PaO}_{2}$ (Table 2). The increase in ATP levels coincided with the increase in pulmonary blood flow and the decrease in PVR (Table 3).

The increase in $\mathrm{PaO}_{2}$ in control experiments was associated with a significant increase in left pulmonary blood flow and a decrease in PVR at 10 and 20 min after beginning exposure to $\mathrm{O}_{2}$ (Table 3). 8-PT and cibacron blue caused significant increases in baseline systemic and pulmonary arterial pressures and PVR (Table 3). Pretreatment of fetal lambs with purine antagonists prevented the decrease in PVR and increase in pulmonary blood flow during the increase in $\mathrm{PaO}_{2}$. Infusion of $\mathrm{U} 46619$ caused significant increases in baseline pulmonary and systemic vascular pressures and PVR. However, U46619 infusion did not attenuate the pulmonary vasodilation caused by $\mathrm{O}_{2}$.

\section{DISCUSSION}

We provide evidence to support our hypothesis that ATP and its metabolite, adenosine, mediate $\mathrm{O}_{2}$-induced pulmonary vasodilation in fetal lambs. The blood and plasma ATP levels in fetal pulmonary circulation increased during an increase in fetal $\mathrm{PaO}_{2}$. Inhibition of receptors for adenosine and ATP caused attenuation of the $\mathrm{O}_{2}$-induced pulmonary vasodilation. We also provide evidence that the purine receptor antagonists used in this study do not alter the response of pulmonary circulation to other endothelium-dependent and -independent vasodilators. The inhibition of $\mathrm{O}_{2}$-induced pulmonary vasodilation caused by these drugs is independent of their effects on baseline pulmonary vascular tone. These studies show that 8 -PT and cibacron blue cause attenuation of $\mathrm{O}_{2}$-induced pulmonary vasodilation by a specific effect on purine receptors in pulmonary circulation.

$\mathrm{O}_{2}$ appears to be the major stimulus that decreases PVR at birth. Morin et al. (6) have shown that an increase in fetal $\mathrm{PaO}_{2}$ to postnatal levels, without distension of lungs, increases the pulmonary blood flow to levels seen in newborn lambs. The effect of $\mathrm{O}_{2}$ on fetal pulmonary circulation is independent of prostaglandin synthesis (9). Our previous studies (11) indicated that adenosine and ATP are pulmonary vasodilators capable of increasing the pulmonary blood flow to postnatal levels in fetal sheep. The pulmonary vasodilation caused by ATP is also independent of prostaglandin synthesis $(11,13)$. An increase in ATP concentrations in the pulmonary artery of fetal lambs to levels seen in postnatal lambs resulted in pulmonary vasodilation of the magnitude seen at birth (11). In the present experiments, we 

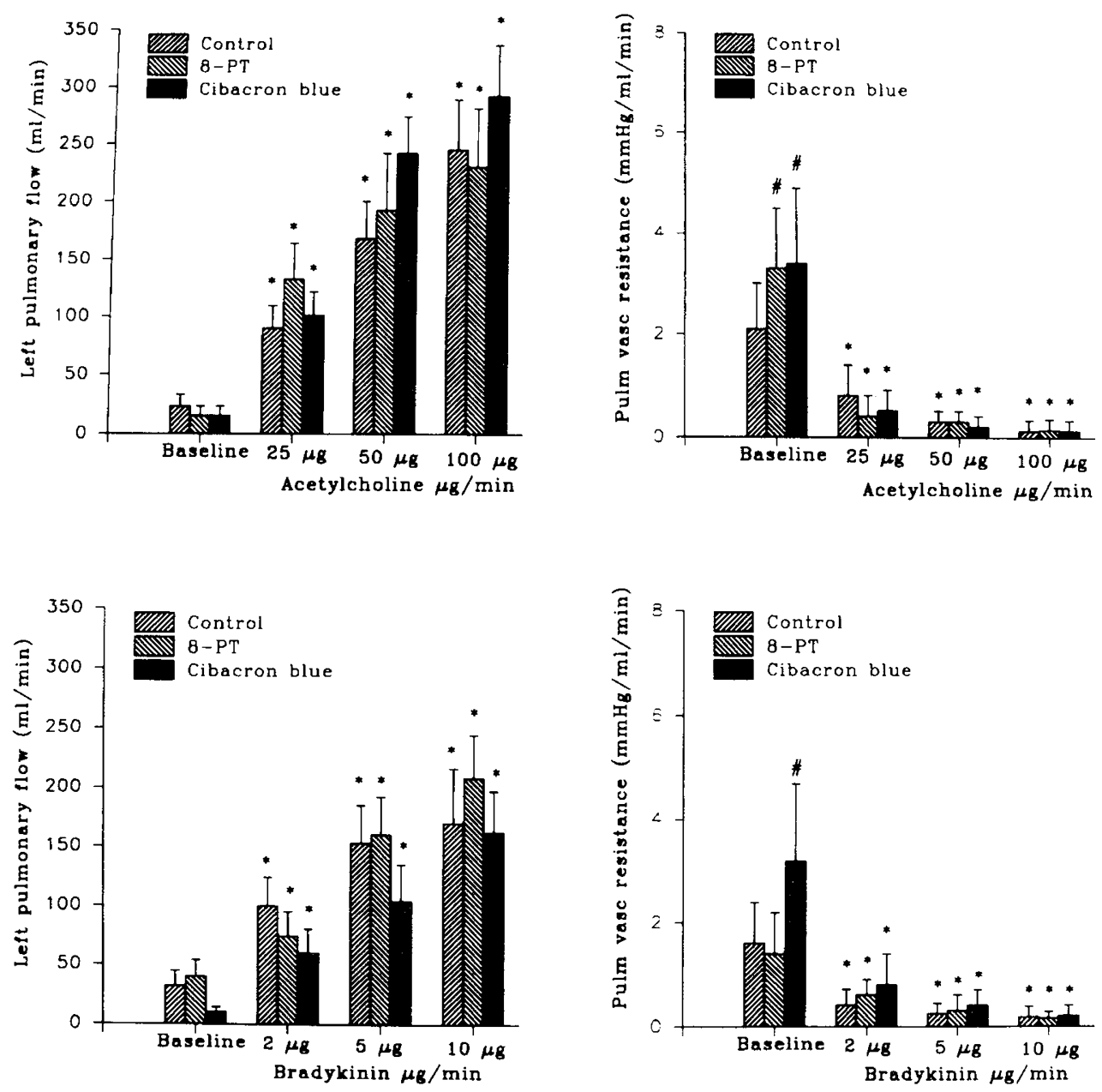

Fig. 1. Effects of 8-PT and cibacron blue on pulmonary vascular effects of acetylcholine and bradykinin in fetal lambs. Baseline data for 8-PT and cibacron blue were obtained $20 \mathrm{~min}$ after their administration. Control, 8-PT, and cibacron blue experiments were done on separate days. Each dose of acetylcholine and bradykinin was given as a continuous infusion for $10 \mathrm{~min}$, and data were obtained at the end of 10 -min. Data are mean $\pm \mathrm{SD}$ for $n=4 .{ }^{*}, p<0.05$ from baseline for each study group; $\#, p<0.05$ from control data obtained at the same time point.
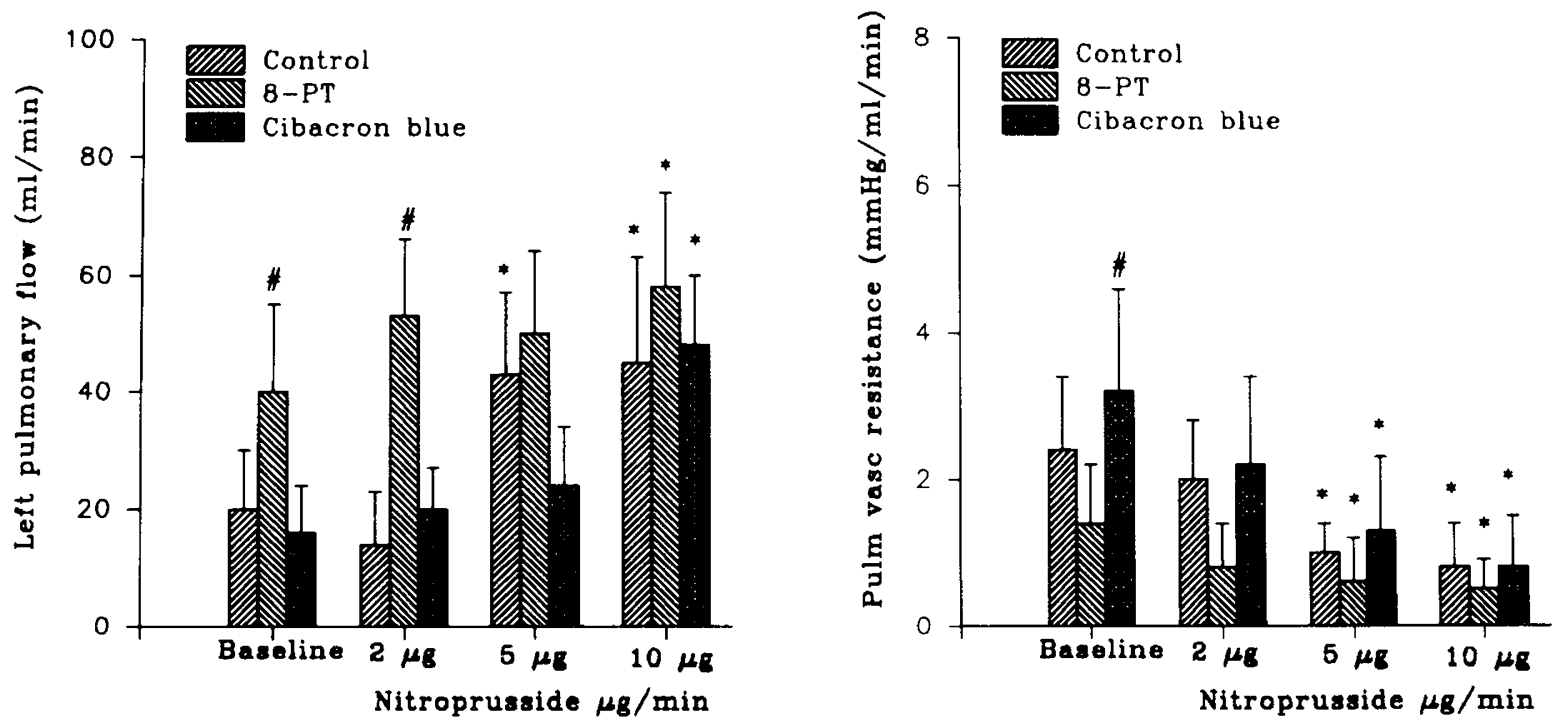

Fig. 2. Effects of 8-PT and cibacron blue on pulmonary vascular effects of nitroprusside. Baseline data for 8-PT and cibacron blue were obtained $20 \mathrm{~min}$ after their administration. Control, 8-PT, and cibacron blue experiments were done on separate days. Each dose of nitroprusside was given as a continuous infusion for $10 \mathrm{~min}$, and data were obtained at the end of $10 \mathrm{~min}$. Data are mean \pm SD for $n=4 .^{*}, p<0.05$ from baseline for each study group; \#, $p<0.05$ from control data obtained at the same time point. 
Table 1. Fetal arterial blood gas values and $\mathrm{pH}$ data during exposure of pregnant ewe to $100 \% \mathrm{O}_{2}{ }^{*}$

\begin{tabular}{|c|c|c|c|c|c|c|}
\hline \multirow[b]{2}{*}{ Variable } & \multicolumn{3}{|c|}{ Control } & \multicolumn{3}{|c|}{ 8-PT + cibacron blue } \\
\hline & Baseline & $10 \min \mathrm{O}_{2}$ & $20 \min \mathrm{O}_{2}$ & Baseline & $10 \min \mathrm{O}_{2}$ & $20 \min \mathrm{O}_{2}$ \\
\hline $\mathrm{pHa}$ & $7.39 \pm 0.03$ & $7.38 \pm 0.03$ & $7.38 \pm 0.03$ & $7.37 \pm 0.04$ & $7.35 \pm 0.04 \dagger$ & $7.35 \pm 0.03 \dagger$ \\
\hline $\mathrm{PaCO}_{2}(\mathrm{~mm} \mathrm{Hg}) \ddagger$ & $35 \pm 4$ & $37 \pm 4$ & $39 \pm 2 \uparrow$ & $36 \pm 3$ & $38 \pm 2$ & $39 \pm 3 \dagger$ \\
\hline $\mathrm{PaO}_{2}(\mathrm{~mm} \mathrm{Hg}) \ddagger$ & $18 \pm 2$ & $24 \pm 3 \dagger$ & $25 \pm 3 \dagger$ & $18 \pm 3$ & $25 \pm 4 \dagger$ & $25 \pm 3 \uparrow$ \\
\hline $\begin{array}{l}\text { Hb concentration } \\
\qquad(\mathrm{g} / \mathrm{dL}) \S\end{array}$ & $9.4 \pm 1$ & $9.7 \pm 1$ & $9.4 \pm 1$ & $9.4 \pm 1$ & $9.2 \pm 1$ & $9.4 \pm 1$ \\
\hline $\mathrm{Hb} \mathrm{O}_{2}$ Sat $(\%)$ & $59 \pm 6$ & $71 \pm 8 \dagger$ & $72 \pm 9 \dagger$ & $58 \pm 9$ & $74 \pm 9 \dagger$ & $71 \pm 9 \dagger$ \\
\hline
\end{tabular}

* Data are shown as mean $\pm \mathrm{SD}$ for $n=12$. Values are corrected to the animal's body temperature. $\mathrm{pHa}$, arterial $\mathrm{pH}$.

$\dagger p<0.05$ from baseline.

$\ddagger$ Conversion factor for SI units: $1 \mathrm{~mm} \mathrm{Hg}=0.133 \mathrm{kPa}$.

$\S$ Conversion factor for SI units: $1 \mathrm{~g} / \mathrm{dL}=10 \mathrm{~g} / \mathrm{L}$.

Table 2. Blood ATP levels in fetal pulmonary circulation during exposure of pregnant ewe to $100 \% \mathrm{O}_{2}{ }^{*}$

\begin{tabular}{ccccc}
\hline Variable & Sample site & Baseline & $10 \min \mathrm{O}_{2}$ & $20 \mathrm{~min} \mathrm{O}_{2}$ \\
\hline Blood ATP levels $(\mu \mathrm{mol} / \mathrm{L})$ & PA & $33 \pm 5$ & $40 \pm 6$ & $46 \pm 7 \dagger$ \\
& LA & $47 \pm 9$ & $58 \pm 8 \dagger$ & $69 \pm 12 \dagger$ \\
Plasma ATP levels $(\mu \mathrm{mol} / \mathrm{L})$ & PA & $0.31 \pm 0.1$ & $0.41 \pm 0.1 \dagger$ & $0.54 \pm 0.1 \dagger$ \\
& LA & $0.36 \pm 0.1$ & $0.48 \pm 0.08 \dagger$ & $0.72 \pm 0.15 \dagger$ \\
\hline
\end{tabular}

* Data are mean $\pm \mathrm{SD}$ for $n=12$. Blood ATP levels were measured in whole blood treated with trichloroacetic acid and reflect combined plasma and red cell pools of ATP. Plasma ATP levels were measured in EDTA-treated samples after red cells were removed. PA, pulmonary artery; LA, left atrium.

$\dagger p<0.05$ from baseline.

Table 3. Effects of 8-PT, cibacron blue, and U46619 on systemic and pulmonary vascular response to $\mathrm{O}_{2}$ in fetal lambs*

\begin{tabular}{|c|c|c|c|c|}
\hline Variable & Study & Baseline & $10 \min \mathrm{O}_{2}$ & $20 \min \mathrm{O}_{2}$ \\
\hline \multirow[t]{3}{*}{ Heart rate $(\mathrm{bpm})$} & Control & $168 \pm 19$ & $165 \pm 12$ & $178 \pm 20$ \\
\hline & U46619 & $168 \pm 10$ & $153 \pm 19$ & $162 \pm 18$ \\
\hline & 8-PT + cibacron blue & $166 \pm 16$ & $166 \pm 21$ & $180 \pm 21$ \\
\hline \multirow[t]{3}{*}{$\mathrm{SAP}(\mathrm{mm} \mathrm{Hg})$} & Control & $51 \pm 3$ & $49 \pm 4$ & $49 \pm 4$ \\
\hline & U46619 & $60 \pm 6 \dagger$ & $61 \pm 6 \dagger$ & $62 \pm 6 \dagger$ \\
\hline & 8-PT + cibacron blue & $59 \pm 4 \dagger$ & $59 \pm 6 \dagger$ & $62 \pm 7 \dagger$ \\
\hline \multirow[t]{3}{*}{$\mathrm{PAP}(\mathrm{mm} \mathrm{Hg})$} & Control & $52 \pm 3$ & $52 \pm 4$ & $52 \pm 4$ \\
\hline & U46619 & $60 \pm 4 \uparrow$ & $62 \pm 5 \uparrow$ & $62 \pm 6 \dagger$ \\
\hline & 8-PT + cibacron blue & $59 \pm 5 \dagger$ & $62 \pm 6+$ & $63 \pm 6+$ \\
\hline \multirow[t]{3}{*}{$\mathrm{LAP}(\mathrm{mm} \mathrm{Hg})$} & Control & $4 \pm 2$ & $5 \pm 3$ & $8 \pm 3 \neq$ \\
\hline & U46619 & $6 \pm 2$ & $7 \pm 3$ & $7 \pm 2$ \\
\hline & 8-PT + cibacron blue & $5 \pm 2$ & $6 \pm 3$ & $6 \pm 2$ \\
\hline \multirow[t]{3}{*}{ Left pulmonary flow $(\mathrm{mL} / \mathrm{min})$} & Control & $20 \pm 10$ & $48 \pm 19+$ & $68 \pm 18 \ddagger$ \\
\hline & U46619 & $17 \pm 9$ & $40 \pm 11+$ & $60 \pm 10 \ddagger$ \\
\hline & 8-PT + cibacron blue & $22 \pm 10$ & $19 \pm 11 \dagger$ & $16 \pm 12 \dagger$ \\
\hline \multirow[t]{3}{*}{$\operatorname{PVR}(\mathrm{mm} \mathrm{Hg} / \mathrm{mL} / \mathrm{min})$} & Control & $2.6 \pm 0.8$ & $1.6 \pm 1 \ddagger$ & $1.1 \pm 0.8 \ddagger$ \\
\hline & U46619 & $3.4 \pm 1 \dagger$ & $2.1 \pm 1.2 \ddagger$ & $1.4 \pm 1+$ \\
\hline & 8-PT + cibacron blue & $3.3 \pm 1 \dagger$ & $3.5 \pm 1.2 \dagger$ & $3 \pm 1.1 \dagger$ \\
\hline
\end{tabular}

* Data are mean \pm SD for $n=16$ for control and 8-PT + cibacron blue and $n=4$ for U46619. SAP, systemic pressure; PAP, left pulmonary artery pressure; LAP, left atrial pressure. Data for U46619 were obtained during continuous infusion of U46619 into left pulmonary artery at 0.75 $\mu \mathrm{g} / \mathrm{min}$ and data for 8-PT + cibacron blue, $20 \mathrm{~min}$ after bolus doses of 8-PT and cibacron blue into left pulmonary artery and during subsequent exposure to $\mathrm{O}_{2}$.

$\dagger p<0.05$ from control data obtained at same time point.

$\ddagger p<0.05$ from baseline for each study group.

have shown that blood and plasma ATP levels in pulmonary artery and left atrium increase during an increase in fetal $\mathrm{PaO}_{2}$.

The source of increased ATP in plasma during exposure to $\mathrm{O}_{2}$ can be red cells or vascular endothelial cells. Our data indicate an increase in both whole blood and plasma levels of ATP. The difference between the two values reflects predominantly red cell ATP, because the contribution of ATP from white cells and platelets is negligible. The increase in $\mathrm{PaO}_{2}$ and $\mathrm{Hb} \mathrm{O}_{2}$ Sat may enhance synthesis and release of ATP by red cells into plasma. The blood ATP levels in left atrium were higher than the levels in pulmonary artery, both at baseline and during the increase in $\mathrm{PaO}_{2}$. The left atrial blood in fetus represents predominantly the umbilical venous blood, which has a higher $\mathrm{PO}_{2}$ than pulmonary arterial blood (21). The observation of higher blood ATP levels in the left atrium is consistent with an increase in red cell ATP levels during an increase in $\mathrm{PaO}_{2}$. However, the mechanism by which the red cell increases ATP production during increased $\mathrm{O}_{2}$ availability is not clear. The mature $\mathrm{RBC}$ does not have the enzymes necessary for oxidative phosphorylation and generates ATP predominantly by glycolysis (22). Therefore, an increase in red cell ATP synthesis during an increase in $\mathrm{PO}_{2}$ does not appear likely in a mature RBC. Reticulocyte and its precursors are capable of oxidative phosphorylation (22). Chen et al. (23) have reported that human fetal $\mathrm{RBC}$ contain mitochondrial forms of isocitrate dehydrogenase, phosphoglucomutase, and other enzymes of oxidative phosphorylation. Whether these enzymes are functionally active in fetal RBC is not known and requires further study. Vascular endothelial cells may also contribute to the 
increase in plasma ATP levels, because these cells are in contact with plasma and contain mitochondria. The increase in fetal blood ATP levels during exposure to $\mathrm{O}_{2}$ is similar to that observed during infusion of exogenous ATP at 0.08 to $0.15 \mu \mathrm{mol} / \mathrm{kg} / \mathrm{min}$ in fetal lambs (11). We reported (11) that infusion of ATP at these doses causes a 3-fold increase in pulmonary blood flow, similar to that observed during exposure to $\mathrm{O}_{2}$. Therefore, the changes in blood ATP levels during $\mathrm{O}_{2}$ exposure correlate well with the hemodynamic effects of ATP on fetal pulmonary circulation.

The purine nucleotides appear to exert their vasodilator effects by stimulation of specific receptors present on endothelial and smooth muscle cells of blood vessels. Burnstock (24) proposed that the effects of purine nucleotides are mediated by two types of purinergic receptors. $P_{1}$ receptors are more sensitive to adenosine, act via the adenylate cyclase system, and are inhibited by methylxanthines. $P_{2}$ receptors are more sensitive to ATP and are not antagonized by methylxanthines. Based on receptor affinity and ligand binding studies, $P_{1}$ receptors have been further classified into $A_{1}$ and $A_{2}$ subtypes. $A_{1}$ receptors inhibit adenylate cyclase and appear predominantly in heart, where they mediate the negative chronotropic and inotropic effects of adenosine (25). $\mathrm{A}_{2}$ receptors are present on the vascular endothelial cells, stimulate adenylate cyclase, and mediate the vasodilator effects of adenosine (25). $\mathrm{P}_{2}$ receptors are also classified into $\mathrm{P}_{2 \mathrm{x}}, \mathrm{P}_{2 \mathrm{y}}, \mathrm{P}_{2 \mathrm{z}}$, and $P_{2 t}$ receptors $(25)$. The relative predominance of these receptors on the cell varies among different organs, $\mathrm{P}_{2 y}$ receptors being more predominant in the lung. Stimulation of purine receptors on endothelial cells is accompanied by release of EDNO and prostacyclin (ATP). Both adenosine and ATP have been shown to cause endothelium-dependent vasodilation in newborn (14) and fetal lambs (15). The pulmonary vasodilation caused by $\mathrm{O}_{2}$ in fetal lambs has been shown to be mediated predominantly by EDNO (10). However, the mechanism by which $\mathrm{O}_{2}$ stimulates the synthesis and release of EDNO is not clear. Increased synthesis and release of ATP during an increase in availability of $\mathrm{O}_{2}$ may serve as a mechanism to trigger the EDNO release and subsequent vasodilation. In addition, adenosine and ATP have direct effects on vascular smooth muscle $(26,27)$ and elicit vasodilation by mechanisms independent of EDNO. These additional mechanisms may confer redundancy to the vasodilator system and facilitate pulmonary vasodilation at birth, a critical step to achieve postnatal survival.

The increase in baseline PVR by the administration of purine antagonists indicates a role for purine nucleotides in maintaining pulmonary vascular tone in the baseline state. The increase in vascular tone caused by purine antagonists may have an independent effect on response of pulmonary circulation to $\mathrm{O}_{2}$. However, infusion of U46619 to increase the baseline PVR did not attenuate the effects of $\mathrm{O}_{2}$ on pulmonary circulation. The increase in PVR during U46619 infusion was of the same magnitude as that caused by purine blockers. The increase in fetal $\mathrm{PaO}_{2}$ was similar in control and purine blocker experiments. The decrease in blood $\mathrm{pH}$ after the administration of purine antagonists may also increase the PVR and attenuate the pulmonary vasodilation caused by $\mathrm{O}_{2}$. However, the decrease in $\mathrm{pH}$ was small, and previous studies by Accurso et al. (5) have shown significant fetal pulmonary vasodilation by $\mathrm{O}_{2}$ at a $\mathrm{pH}$ of 7.34, with even a smaller increase in $\mathrm{PaO}_{2}$, compared with our experiments. There was a small but significant increase in fetal $\mathrm{PaCO}_{2}$ in both control and purine blocker experiments during exposure to $100 \% \mathrm{O}_{2}$, as previously reported $(5,6)$ during exposure of the ewe to $100 \% \mathrm{O}_{2}$. The increase in $\mathrm{PaCO}_{2}$ is probably due to a decrease in systemic and placental flow caused by the increase in pulmonary flow.

8-PT, the $\mathrm{P}_{1}$ antagonist used in our study, is 100 times more potent than theophylline at adenosine receptors and is devoid of effects on phosphodiesterase (25). Theophylline and 8-PT are not selective for $A_{2}$ receptors, which mediate vasodilator effects of adenosine. However, $A_{1}$ receptors mediate the negative chron- otropic and inotropic effects of adenosine, and inhibition of these receptors should not limit the increase in pulmonary flow caused by $\mathrm{O}_{2}$. Cibacron blue has been shown to cause $\mathrm{P}_{2 y}$ receptor inhibition in canine coronary arteries (28). However, the specificity of this blocker for $\mathrm{P}_{2 \mathrm{y}}$ receptor in fetal pulmonary arteries has not been established previously. Our studies indicate that cibacron blue, in a dose of $5 \mathrm{mg} / \mathrm{kg}$, does not interfere with vasodilation caused by other endothelium-dependent and -independent vasodilators. We conclude that the inhibition of $\mathrm{O}_{2^{-}}$ induced pulmonary vasodilation in our studies was due to specific inhibition of $P_{1}$ and $P_{2}$ purinergic receptors.

Previous studies in adult animals have shown that adenosine levels in coronary and cerebral circulations increase $(17,18)$ during hypoxia. However, the response of pulmonary vessels to changes in $\mathrm{O}_{2}$ tension is opposite to that of systemic vessels. We previously reported (12) that plasma adenosine levels in pulmonary artery and left atrium in newborn lambs decrease during alveolar hypoxia. We now report an increase in ATP levels in pulmonary artery during an increase in $\mathrm{PaO}_{2}$. The differences in release of nucleotides between pulmonary and systemic vessels may partly account for their different responses to $\mathrm{O}_{2}$ and hypoxia.

In summary, our studies indicate that adenosine and ATP have a significant role in the mediation of pulmonary vasodilation caused by $\mathrm{O}_{2}$ in fetal lambs. The plasma ATP levels in pulmonary circulation increase during $\mathrm{O}_{2}$-induced pulmonary vasodilation, and inhibition of receptors for adenosine and ATP causes significant attenuation of $\mathrm{O}_{2}$-induced pulmonary vasodilation. Their role as mediators of birth-associated changes in pulmonary circulation requires further investigation in fetal lambs.

\section{REFERENCES}

1. Dawes GS, Mott JC, Widdicombe JG, Wyatt DG 1953 Changes in the lungs of the newborn lamb. J Physiol (Lond) 121:141-162

2. Cassin S, Dawes GS, Mott JC, Ross BB, Strang LB 1964 The vascular resistance of the foetal and newly ventilated lung of the lamb. J Physiol (Lond) 171:6179

3. Assali NS, Kirschbaum TH, Dilts PV 1968 Effects of hyperbaric oxygen on uteroplacental and fetal circulation. Circ Res 22:573-588

4. Heymann MA, Rudolph AM, Nies AS, Mamon KL 1969 Bradykinin production associated with oxygenation of the fetal lamb. Circ Res 25:521-534

5. Accurso FJ, Alpert B, Wilkening RB, Petersen RG, Meschia G 1986 Timedependent response of fetal pulmonary blood flow to an increase in fetal oxygen tension. Respir Physiol 63:43-52

6. Morin FC, Egan EA, Ferguson W, Lundgren CEG 1988 Development of pulmonary vascular response to oxygen. Am J Physiol 254:H542-H546

7. Leffler CW, Tyler TL, Cassin S 1978 Effect of indomethacin on pulmonary vascular response to ventilation of fetal goats. Am J Physiol 234:H346-H351

8. Velvis H, Moore P, Heymann MA 1991 Prostaglandin inhibition prevents the fall in pulmonary vasuclar resistance as a result of rhythmic distension of the lungs in fetal lambs. Pediatr Res 30:62-68

9. Morin FC, Egan EA, Norfleet WT 1988 Indomethacin does not diminish the pulmonary vascular response of the fetus to increased oxygen tension. Pediatr Res 24:696-700

10. Abman SH, Chatfield BA, Hall SL, McMurtry IF 1990 Role of endotheliumderived relaxing factor during transition of pulmonary circulation at birth. Am J Physiol 259:H1921-H1927

11. Konduri GG, Theodorou AA, Mukhopadhyay A, Deshmukh DR 1992 Adenosine triphosphate and adenosine increase the pulmonary blood flow to postnatal levels in fetal lambs. Pediatr Res 31:451-457

12. Konduri GG, Woodard LL, Mukhopadhyay A, Deshmukh DR 1992 Adenosine is a pulmonary vasodilator in newborn lambs. Am Rev Respir Dis 146:670-676

13. Konduri GG, Woodard LL 1991 Selective pulmonary vasodilation by low dose infusion of adenosine triphosphate in newborn lambs. J Pediatr 1 19:94-102

14. Fineman JR, Heymann MA, Soifer SJ 1991 N-nitro-L-arginine attenuates endothelium-dependent pulmonary vasodilation in lambs. Am J Physiol 260:H1299-H1306

15. Konduri GG, Theodorou AA 1992 Nitro-L-arginine attenuates pulmonary vasodilation caused by adenosine in fetal lambs. Pediatr Res 31:62A(abstr)

16. Dieterle Y, Ody C, Ehrensberger A, Stalder H, Junod AF 1978 Metabolism and uptake of adenosine triphosphate and adenosine by porcine aortic and pulmonary endothelial cells and fibroblasts in culture. Circ Res 42:869-876

17. Berne RM 1980 The role of adenosine in the regulation of coronary blood flow. Circ Res 47:807-813

18. Morii S, Ngai AC, Ko KR, Winn HR 1987 Role of adenosine in regulation of cerebral blood flow: effects of theophylline during normoxia and hypoxia. Am J Physiol 253:H165-H175 
19. Leach FR 1981 ATP determination with firefly luciferase. J Appl Biochem 3:473-517

20. Winer BJ 1971 Statistical Principles in Experimental Design. McGraw-Hill Book Co, New York, pp 514-603

21. Rudolph AM, Heymann MA 1970 Circulatory changes during growth in the fetal lamb. Circ Res 26:289-299

22. Frisell WR 1982 Human Biochemistry. McMillan Publishing Co, New York, pp 422-445

23. Chen SJ, Anderson JE, Giblett ER, Stamatoyannopoulos G 1977 Isozyme patterns in erythrocytes from human fetuses. Am J Hematol 3:23-28

24. Burnstock G 1990 Overview: purinergic mechanisms. Ann NY Acad Sci 603:118
25. Paton DM, Taerum T 1990 A comparison of $\mathrm{P}_{1}$ - and $\mathrm{P}_{2}$-purinoceptors. Ann NY Acad Sci 603:165-171

26. Ramagopal MV, Mustafa SJ 1988 Effect of adenosine and its analogs on calcium influx in coronary artery. Am J Physiol 255:H1492-H1498

27. Chen G, Suzuki H 1991 Endothelium-dependent hyperpolarization elicited by adenine compounds in rabbit carotid artery. Am J Physiol 260:H1037$\mathrm{H} 1042$

28. Houston DA, Burnstock G, Vanhoutte PM 1987 Different $P_{2}$-purinergic receptor subtypes of endothelium and smooth muscle in canine blood vessels. J Pharmacol Exp Ther 241:501-506

\section{Announcement}

\section{Paediatric Week Holland}

The Paediatric Week Holland will be organized in Rotterdam, The Netherlands from June 29 to July 6, 1994. From July 3 through July 6, a combined meeting will be held of the European Society for Paediatric Research, the European Paediatric Respiratory Society, the European Respiratory Society-Paediatric Assembly, the European Society of Paediatric Allergy/Clinical Immunology, the European Society for Paediatric Infectious Diseases, the European Society of Paediatric Intensive Care, and the European Society for Paediatric Hematology and Immunology. From June 29 through July 2, the British Association of Paediatric Surgeons will meet, and the Dutch Society of Psychosocial Consultation and Paediatrics will meet from July 3 through July 5. Postgraduate courses will be organized in the overlapping weekend. For further information, please contact: Pieter J. J. Sauer, M.D., c/o Erasmus University Rotterdam, P.O. Box 1738, NL-3000 DR Rotterdam, The Netherlands. 